\title{
BULLETIN OF THE GEOLOGICAL SOCIETY OF AMERICA
}

VOL. 32, PP. 327-332

SEPTEMBER 1, 1921

PROCEEDINGS OF THE PALEONTOLOGICAL SOCIETY

\section{EVOLUTION, PHYLOGENY, AND CLASSIFICATION OF 'THE MASTODONTOIDEA ${ }^{1}$}

BY HENRY FAIRFIELD OSBORN

(Presented before the Paleontological Society December 30, 1920)

\section{CONTENTS}

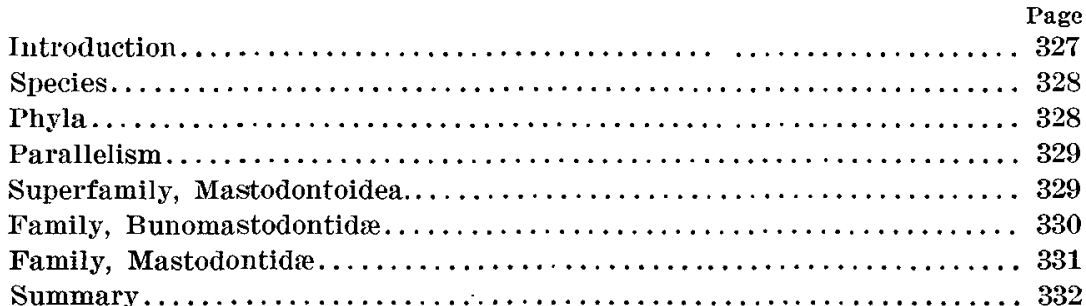

\section{INTRODUCTION}

In previous papers reasons have been given for dividing the Proboscidea into four main superfamilies, as follows:

I. Moritherioidea, typified by Moritherium, Oligocene, North Africa.

II. Dinotherioidea, typified by Dinotherium, Miocene and Pliocene, Eurasia.

III. Mastodontoidea, typified by the bunomastodonts and the mastodonts, Africa, Eurasia, North and South America.

IV. Elephantoidea, typified.by the stegodonts, loxodonts, elephants, and mammoths, Africa, Eurasia, North America.

\footnotetext{
${ }^{1}$ Manuscript received by the Secretary of the Society May 10, 1921.

This is the fourth paper of the series. The first paper, entitled " $A$ long-jawed mastodon skeleton from South Dakota and phylogeny of the Proboscidea," appeared in the Bull. Geol. Soc. Am., vol. 29, No. 1, March, 1918, pp. 133-137. The second paper, entitled "Evolution, phylogeny, and classification of the Proboscidea," appeared in Amer. Mus. Novitates, No. 1, January 31, 1021 (1921. 514). The third paper appeared in Amer. Mus. Novitates, No. 10, Jine 15, 1921, under the title "First appearance of the true mastodon in Amcrica."
} 
As clearly pointed out in the second paper on this subject (Osborn, 1921. 514, pages 2-5), these four superfamilies are clearly distinguished from each other by profound differences in the adaptations of the cutting teeth, namely, the first and second pairs of superior and inferior incisors characteristic of all Proboscidea. The author is not prepared at present to add to what has been said in previous papers regarding the mœritheres and dinotheres.

\section{SPECIES}

Continued observation of the types on which the species in all parts of the world have been founded and of the genotypes from which the genera received their designations is gradually bringing order out of chaos. The synonymy in the 47 generic names is most difficult of solution. There is far less synonymy among the species; in fact, the specific and subspecific stages are far more numerous than has hitherto been supposed. It is not proposed at present, however, to multiply the species; rather to attempt to arrange the 170 or more species hitherto described in their natural lines of phyletic descent.

\section{Phyla}

There are still wide differences of opinion about the reality of the polyphyletic division of the Proboscidea. Such division is still considered a matter of theory, whereas it will be shown to rest on actual demonstration of a very profound divergence of many lines, due to the principles of adaptive radiation, local and continental.

In 1918 I divided the Proboscidea into ten phyla. In 1921 I divide them into twelve phyla. The application of generic names to these phyla presents a very difficult problem in nomenclature, on which $I$ am securing the cooperation and advice of all the experts on this subject, especially of such leading authorities as Allen, Palmer, Matthew, Andrews, and Schlesinger. The difficulty arises from the fact, pointed out in my first paper, that the generic names were based on species which belonged within two, three, and sometimes four distinct phyla. For example, the generic name Tetralophodon Warren, 1852, was based on the species $M$. latidens, $M$. arvernensis, $M$. sivalensis, animals which certainly belong to two distinct phyla-stegodontines and brevirostrines. The same term, Tetralophodon, was applied by Falconer in 1857 to animals belonging to four distinct phyla, namely, $M$. longirostris (a longirostrine), $M$. latidens (a stegodontine), $M$. andium (an American brevirostrine), $M$. arvernensis and $M$. sivalensis (two Eurasiatic brevirostrines). The name Tetralophodon Falconer would apply admirably to $M$. longirostris, but unfortunately it 
is preoccupied by Warren for $M$. latidens, $M$. arvernensis, etcetera, and therefore can not be used.

\section{Paralleltsm}

Again it is said that there are transitions between certain of these phyla ; for example, between the longirostrines and the brevirostrines in the Pliocene of Europe. Such transitions may be observed in single structures, because the law of parallel evolution is constantly at work; for example, in the family Bunomastodontidæ there are at least four clearly distinct phyla, which we may at present separate as the longirostrines, the rhynchorostrines, the South American brevirostrines ( $M$. andium, $M$. humboldtii), and the American Trilophodon serridens phylum (unnamed at present). All these animals are united by the common possession of the bunomastodont type of molars, composed of compressed inner and outer lobes, to which Cuvier applied the original term "mastodon," between which sprang up also single bunoid intermediate cones forming trefoils (Phiomia, Trilophodon), then gradually both internal and extermal trefoils, such as are found in the long-jawed $M$. campester and $M$. longirostris and independently arise in the short-jawed $M$. humboldtii. Thus the internal and external pairs of trefoils develop by parallelism in four separate lines of descent in the phyla belonging in the new family of Bunomastodontidæ (Osborn, 1921. 514), the phyla being united by this common family character as well as by the presence of a broad enamel band on the superior incisor teeth. They are still more clearly separated from each other by the elongation or by the abbreviation of the jaw or by the formation of a downturned or beaked jaw.

It is by this interpretation of the facts of descent, and by the exclusion of parallelism, and not by theory that we reach the polyphyletic subdivision of the Mastodontoidea, as follows:

\section{Superfamily, Mastodontomea}

Family, Mastodontides

Grinding teeth lophodont, no intermediate cones or trefoils; all grinders with simple transverse crests; intermediate grinders evolving from two to three crests.

Lower jaw gradually reduced in length.

Inferior canines, rounded tusks, not functional.

\section{Family, Bunomastodontide}

Grinders bunomastodont, with single developing into double trefoils; intermediate grinders evolving from three into four crests.

Upper tusks with broad, persistent enamel band on outer concave surface, abrading the lower tusks.

Lower tusks horizontal, oval or downturned, with or without enamel band. 
Superior canines, rounded upcurved tusks, with enamel band on convex outer surface, gradually disappearing.

Subfamily, Mastodontinae (monophyletic)
Subfamilies

(1) Longirostrinæ, (2) Rhynchorostrinæ, (3) Serridentinæ, subfamily nov., (4) Notorostring, subfamily nov., (5) Brevirostrinæ.

Genus, Paloxomastodon, Oligocene.

Genus, Mastodon, Miocene to Pleistocene.

\section{Family, Bunomastodontid}

The Longirostrinæ (1) and the Rhynchorostrinæ (2), also the Brevirostrinæ (5), have been clearly defined in previous papers.

(3) The Serridentince apparently spring from $M$. turicense Schinz, 1824, of the Middle Miocene of France and Switzerland-a rare animal, probably because a forest dweller. The grinders are readily distinguished by a prominent spur which projects from the inner apex of the crests in the lower teeth and from the outer apex of the crests in the upper teeth. It is recognized again in the Miocene Siwaliks of India. It appears again in the Lower Pliocene (Trilophodon serridens Cope) of the Clarendon beds of Texas; also in the T. serridens cimarronis of Texas, represented in the American Museum collection by a hitherto undescribed complete skull, which proves that this phylum belongs near the Bunomastodontinæ, although the grinding teeth lack the trefoils characteristic of that phylum. These animals have usually been placed with $M$. tapiroïdes of the lophodont or mastodontine phyla of France. They certainly possess cutting teeth of bunomastodont type and are probably remote from the true mastodontines.

(4) The Notorostrince include all the Central and South American brevirostrines, which are also abundant in the southwestern United States-for example, Texas (Blanco formation), Mexico, the Andean, and the Pampean regions. They were distinguished in my second paper as "The brevirostrines of South America," embracing the classic species $M$. andium Cuv., M. humboldtii Cuv.; also $M$. tropicus Cope (Valley of Mexico), M. successor Cope (Blanco of Texas). They possibly sprang from or are related to Eubelodon morrilli Barbour, 1913, from the Lower Pliocene, Nebraska. The fact that these animals are not only profoundly separated from the other bunomastodonts by the progressive abbreviation of the jaw, but that they are the only members of the great order Proboscidea which, so far as known at the present time, entered the South American continent, will probably convince reluctant paleontologists that 
they constitute a distinct subfamily, which may be named the Notorostrinæ, ${ }^{3}$ or short-jawed mastodons of the South American continent. There is a very great variety of form among the ten species which have been described, including, in addition to those mentioned above, $M$. bolivianus Philippi, M. chilensis Philippi, M. platensis Ameg., M. rectus Ameg., $M$. argentinus Ameg., and $M$. superbus Ameg. 'The two beautiful skulls in the Stockholm Museum, referred to M. andium by Nordenskjold, display a spiral twist of the tusks-a feature quite unique among Proboscideans.

\section{Family, Mastodontide}

As pointed out by Matsumoto, the lophodont Paloeomastodon of North Africa is readily distinguished by the absence of intermediate cones and trefoils, which block the valleys in the contemporary genus Phiomia; its grinding teeth are purely crested or lophodont. It is also distinguished by its bilophodont superior intermediate molars, whereas those of Phiomia are fully trilophodont. The lower intermediate molars of Palcomastodon have only two complete crests and one small lobe representing a third crest instead of the complete third crest of Phiomia. Thus they have not attained the trilophodont stage characteristic of the genus Mastodon, but may lead into that stage. Although the skull is not fully known, it is relatively broader and shorter than that of Phiomia. The relative rarity of this animal in both the American Museum and British Museum collections is also in keeping with the theory that it was a forest dweller and that its remains, like those of all the Mastodontinæ, escaped fossilization until the true mastodons appear in enormous abundance in the Pleistocene forest formations of eastern North America.

It now appears probable that the Mastodontidæ sprang from the genus Palceomastodon of the Oligocene Fayûm deposits of North Africa, while the Bunomastodontidæ sprang from the genus Phiomia of the same deposits. From materials in the American Museum hitherto undescribed, Matsumoto has positively separated these two genera, the species of which have been more or less confused ever since the original descriptions of Andrews of Palcomastodon in 1901 and of Phiomia in 1902. Phiomia is certainly ancestral to the Bunomastodontidæ only, in fact, barely separable generically from Trilophodon angustidens, the typical longirostrine.

The name Palcomastodon, which has figured in all the literature from the date of its establishment to the present author's preceding paper (1921. 514), therefore applies only to the lophodont type of $P$. beadnelli,

\footnotetext{
3 From the Latin of Virgil, "notus," a southwest wind; Greek, "Notogæa," the South
} American region.

XXIII-Buld. GeoL, Soc. AM., Vol. 32, 1920 
on which it was founded, and can not be applied to the bunomastodont genotype of Phiomia, which was founded a year later by the same author. There is no question as to the absolute phyletic distinction between these two animals, but until the cutting teeth of Palcomastodon beadnelli are known we can not be sure that this animal is directly ancestral to the Mastodontidæ, as would appear.

Schlesinger has added several very important examples of true mastodons from the Lower and Middle Pliocene of Hungary, to which he gives the name $M$. tapiroides americanus. ${ }^{4}$ The first appearance of the true mastodon in North America is in the Snake Creek formation, Lower Pliocene of western Nebraska, where a few teeth have been found by the American Museum and Princeton parties, one of which has been selected by Osborn as the type of Mastodon matthewi. ${ }^{5}$ Its next occurrence is in the Thousand Creek formation of Nevada, Middle Pliocene, represented by two posterior grinding teeth in the collections of the Colorado Museum of Natural History, Denver, and of the University of California, which . Osborn has made the type of the species Mastodon merriami, ${ }^{5}$ in honor of President Merriam, of the Carnegie Institution.

These teeth, as well as those of the Lower Pliocene of Hungary, are readily distinguished from those of $M$. americanus by their more brachyodont character; the crests are low and spreading instead of being tall and narrow.

\section{Summary}

Research on this group is still in active progress, and from week to week the conclusions both as to phylogeny and as to classification are modified by the discovery of fresh or hitherto undescribed material and by the more careful analysis of the fundamental characters of the different phyla.

\footnotetext{
1 Characters examined from an important unpublished memoir by Professor Schlesinger, original photographs of which were kindly forwarded to the present author.

${ }^{5}$ Amer. Mus. Novitates, No. 10, June 15, 1921. Immediately after the publication of this paper the author learned that the type of Mastodon merriami occurred in beds of Middle Miocene age, which makes it geologically older than Mastodon matthewi.
} 